\title{
DEPOSIT MUDARABAH INVESTMENT RISK ANALYSIS METHOD VALUE AT RISK (VaR)
}

\author{
Iin Emy Prastiwi \\ Sharia Economics Study Program, Institute of Business Technology-AAS Indonesia \\ Email: iinemyprastiwi24@gmail.com
}

\begin{abstract}
The purpose of this study is to understand the risk and return on net return on mudharabah deposits in Islamic banks using the Value at Risk (VaR) approach. The objects in this study are quarterly financial statements of Bank Syariah Mandiri, Bank BRI Syariah, and Muamalat Bank for three years, 2015-2017. The VaR analysis results show that the average risk of mudharabah deposit investment for 3 years in Bank Syariah Mandiri is 2015 at $6.61 \%$ and net return $-0.53 \%$, in 2016 the risk is $0.14 \%$ and net return $3.21 \%$, in 2017 the risk is $0.17 \%$ and net return is $0.32 \%$. BRI Syariah Bank is 2015 at $0.08 \%$ and net return of $4.28 \%$, in 2016 the risk is $0.07 \%$ and net return $3.77 \%$, in 2017 the risk is $0.08 \%$ and net return $42.81 \%$ . and Bank Muamalat is 2015 at $0.63 \%$ and net return of $0.04 \%$, in 2016 the risk is $0.40 \%$ and net return is $0.08 \%$, in 2017 the risk is $0.14 \%$ and net return is $0.26 \%$. Also, there are differences in the level of risk and return (net return) in Bank Syariah Mandiri, BRI Syariah, and Muamalat Bank with significant probability (pvalue) for the risk level of 0.005 and return (net return) of 0.045. From the risk level and net return for three years, BRI Syariah Bank is a bank that has prospective value.
\end{abstract}

Key Words: VaR, risk, the net return, mudharabah deposit

\section{Introduction}

Islam encourages its people to manage their property productively. Investment is one of the easy ways to produce assets. Investment is a solution for people who cannot produce their wealth in economic activities.

Investment is the teachings of Islam which Islam encourages Muslims to prepare for the future. One of them is investing. In Islamic economics, an investment can reduce poverty and increase income, because assets are used productively.

Investment is always related to profit expectations. An investor must be careful in investing, because an investment is inseparable from the element of uncertainty, risk, and return. Knowledge about risk and how to manage risk is important for investors.

According to Hidayati, (n.d.), uncertainty, loss, fear, volatility, return, investment are words related to investment risks in banking. Investors who make investments will get a return as profit. But behind that, investors also bear the risks that must be faced. Risk is not dangerous if investors have knowledge about risk and can manage the risk. Risk is not something to be avoided but something that must be dealt with will be better because as the popular term we are with "high-risk high return, low-risk low return.

The high level of risk expectations is directly proportional to the expected rate of return. Risk does not have to always be avoided, but something that must be studied, predicted, and carefully prepared (Musthofa \& Prastiwi, 2016). Therefore risk measurement is needed so that 
the risk is still at a controlled level. One method of risk measurement that is quite popular is Value at Risk (VaR) which was popularized by J.P Morgan in 1994 (Zuhara et al., 2012).

Mudharabah deposit investments are guaranteed by the Deposit Insurance Corporation. This is if the bank is a member of the Indonesia Deposit Insurance Corporation. The maximum amount of customer funds guaranteed by the Deposit Insurance Corporation is 2 billion. Even though it has been guaranteed by the Deposit Insurance Corporation, there are still some risks in mudharabah deposit investments. One of them is a low rate of return and is not proportional to inflation. Therefore, depositors need to choose deposits from Islamic banking that can provide the highest return on return, with a minimum level of risk.

Risk is the risk of returns that are given by banks to customers. The risk of return on Islamic banking is different from conventional banking. In mudharabah deposit transactions, the rate of return on mudharabah deposits fluctuates following bank profit from financing distribution activities. Whereas in conventional banking the rate of return remains by the specified interest. This study aims to analyze the level of risk returns on mudharabah deposits at Bank Syariah Mandiri, Bank BRI Syariah, and Bank Muamalat using the Value at Risk (VaR) method.

Several previous studies measure the level of investment risk in banks using the Value at Risk method. Musthofa \& Prastiwi, (2016) examined the level of risk and return with the VaR method. The result is mudharabah deposit investment in Bank Syariah Mandiri, after being measured by the VaR approach, has an investment risk (VaR mean) in 2013-2015 which has a higher return than the risk or a greater return than the VaR mean. Also, the risks and returns of Bank Syariah Mandiri in 2013-2015 are quite stable. Prabowo, (2009) examined the level of risk and returns with the VaR method at Bank Syariah Mandiri. The result is mudharabah deposit investment in Bank Syariah Mandiri tends to be profitable due to VaR (zero) showing a negative value. Also, the average gross expected return to the equivalent rate of mudharabah time deposits (1, 3, 6 and 12 months) is quite stable, due to the volatility of the VaR (mean) and VaR (zero) values which are lower when viewed from the average value gross expected return. Saddique \& Khan, (2016) examined VaR with 3 different methods, namely Variance-Covariance; historical simulations, and Monte Carlo simulations on 18 banks in Pakistan. The results show that the absolute values calculated with the help of each method differ greatly from each other. There is no simple answer which approach is the best, a risk-taking manager can consider VaR another method.

\section{Mudharabah Deposit Investment}

In the Islamic view of the basic investment that needs to be known in Islamic banking, which includes fundraising products is deposits. As for what is meant by sharia deposits are deposits that are run based on sharia principles. In this case, according to the National Sharia Board fatwa Number, 03 / DSN-MUI / IV / 2000 (DSN, 2000) states that the justified deposit is a deposit based on the mudharabah principle. Mudharabah deposits are Islamic bank fundraising products that are quite attractive to banking customers (Prabowo, 2009).

Mudharabah deposits according to Ismail, (2014) are investment funds placed by customers that do not conflict with sharia principles and withdrawals can be made at a certain time, by the contractual agreements entered into by the bank and investor customers. Time deposits typically $1,3,6$, and 12 months.

Islamic investment products from sharia banking besides savings are deposits (Prabowo, 2009). Deposit products are often in demand as a means of investment. Therefore, the contract 
used in deposit products is the mudharabah contract (Al Anshori, 2009). Through the mudharabah agreement, the profit-sharing ratio is determined by both the customer and the Islamic bank itself at the beginning of the agreement. Based on DSN Fatwa No. 3 / DSN-MUI / IV / 2000 in which it is stated that the deposits which are justified in sharia are deposits with mudharabah principle. The depositor's customer is the owner of the fund (shahibul maal) while Islamic banking is the manager of the fund (mudharib). Mudharabah deposit provisions by DSN fatwa No. 3 / DSN-MUI / IV / 2000 are as follows:

a. Mudharabah deposit transactions, the depositor's customer as the owner of the funds (shahibul maal) while Islamic banking as the manager of the funds (mudharib).

b. Fund management by mudharib is carried out in the halal sector and does not conflict with Islamic principles.

c. Capital must be cash, not credit.

d. Distribution of profit from mudharabah deposits in the profit sharing ratio.

e. Islamic banking as mudharib, in meeting operational costs is taken from the profit ratio that is entitled to Islamic banks.

\section{Risk}

Risk according to Prabowo, (2009) is the impossibility of events that have historical precedents and follow a probability distribution, hence risks can be estimated theoretically.

According to the Financial Services Authority Regulation (POJK) No. 18 / POJK.03 / 2016 (Dewan Komisioner OJK, 2016) concerning Application of Risk Management for commercial banks, defines risk as a potential loss due to certain events. Islamic banking is exposed to various risks, such as market risk, credit risk, liquidity risk, and so on. So that Islamic banking needs to implement risk management. Risk management is used to identify, measure, monitor, and control risks from all Islamic banking activities.

The concept of uncertainty in the Islamic economy is one of the important points in the process of Islamic risk management. Naturally, in business activities, in this world no one wants business or investment to suffer losses. Even at the macro level, a country also expects a positive trade balance. The Shariah principle of return and risk is $\mathrm{Al}$ ghunmu bil ghurmi, meaning that risk will always accompany every expectation of return.

The emergence of uncertainty in the Islamic economy is one of the important points in the process of Islamic risk management. In general, in business activities, no one in the world wants business or investment to suffer losses. The Shariah principle of return and risk is $\mathrm{Al}$ ghunmu bil ghurmi, meaning that risk will always accompany any return expectations. There are several types of risks in mudharabah deposit investments, namely the level of return sharing obtained is not proportional to the increase in inflation. The value of money from day to day continues to decrease. Because of this reduced value of money, then the interest from deposits is actually partly used to cover the value of the reduced money.

Risks are distinguished by type (Hermansyah, 2017):

a. Credit risk, which is the risk caused by the debtor in carrying out its obligations as required by the contractual agreement.

b. Country and transfer risks are risks caused by the economic, social and political environmental conditions of the counterparty's home country

c. Market risk, namely the risk caused by market price movements

d. Interest rate risk is the risk caused by the movement of interest rates in the market 
e. Liquidity risk is the risk caused by the inability of banks to accommodate the reduction in liabilities to finance the increase in the asset side.

f. Operational Risk, the risk caused by violations of internal regulations and bank policies.

g. Legal risk, namely risk caused by errors in giving legal opinion and legal documentation

h. Reputational risk, namely risk caused by failures in bank operations, especially failures in meeting legal or regulatory requirements imposed on banks

\section{Return}

Return according to Fahmi, (2011) is the profit obtained by companies, individuals, and institutions from the results of the investment policy carried out. Return the result from investments. There are two types of returns, namely realized returns and expected returns. Realized returns, ie those that have already occurred, are calculated based on historical data. While return expectations (expected returns) that have not occurred but are expected to occur in the future (Jogiyanto, 2015). In stock investing, there are 2 returns, namely (Ismanto, 2016):

a. Capital Gain: the difference between the current stock price and the previous stock price.

b. Dividends: distribution of profits to shareholders based on the number of shares owned.

\section{Risk of Return}

The relationship between return and risk is the same direction, meaning the greater the return, the greater the risk. Every investment is always possible for positive returns, negative returns, or no returns. In existing investments is the relationship between investors and those who produce capital. The right for both parties to profit-sharing when the effort to produce capital has resulted in profits according to the agreement.

The risk of returning results is the risk of returning the results of banking to customers. The risk of return on Islamic banking is different from conventional banking. The rate of return on mudharabah deposits in Islamic banking fluctuates following bank profit from financing distribution activities. Whereas in conventional banking the rate of return remains by the specified interest.

The variation in the amount of daily, monthly returns, and so on is called volatility. Volatility is a measure of risk. Statistically, volatility is measured by variance $\left(\boldsymbol{\sigma}^{\mathbf{2}}\right)$ and standard deviation $(\boldsymbol{\sigma})$. The calculation formula for variance $\left(\boldsymbol{\sigma}^{2}\right)$ and standard deviation $(\boldsymbol{\sigma})$ is as follows:

$$
\begin{aligned}
& \text { variance }\left(\sigma^{2}\right)=\frac{\sum_{1=1}^{N}(\mathbf{r i}-\mathbf{E r})^{2}}{\mathrm{~N}-1} \\
& \text { standard deviation }(\sigma)=\sqrt{\frac{\sum_{1=1}^{\mathrm{N}}(\mathrm{ri}-\mathrm{Er})^{2}}{\mathrm{~N}-1}} \\
& \text { Description: } \\
& \mathrm{ri} \quad=\text { return based on sample observations } \\
& \mathrm{Er} \quad=\text { expected return (average return value) } \\
& \mathrm{N} \quad=\text { number of observations and observations }
\end{aligned}
$$

The greater the standard deviation, the higher the volatility of investment returns, which also means the riskier investment (Ghozali, 2007).

The need to predict reliable risks is getting stronger. The growth of investment activities is large and increasingly uncertain so it is necessary to develop more reliable and accurate risk measurement techniques. Some examples of financial institution bankruptcy events have 
increasingly encouraged the development of risk measurement techniques, including (Ghozali, 2007):

a. The bankruptcy of Barings Bank in February 1995, the total loss reached GBP 827 billion. Nick Leeson who holds the position of general manager, chief trader, and de facto also the head of operations conduct speculation transactions without the approval of superiors in the future that connects the Nikkei with Japanese government bonds. Leeson and his team are responsible for differences in arbitrage prices between the Nikkei Future traded on SIMEX and the Japan Osaka Exchange. Who would have thought that a bank that has been established for more than two centuries must close the bank with its derivative transactions?

b. The bankruptcy of the Oranges County Government in California, United States, in December 1994, due to Robert Citron, his treasurer who speculated on the financial markets. Citron is too brave to take risks by playing with fire in investment instruments (speculation instruments) as a result of financial engineering.

c. Daiwa Bank lost more than the US \$ 1 billion in Treasury Bond trading because Toshihide Iguchi, a trader, hid this potential loss for 11 years and was only revealed after Iguchi admitted in September 1995.

d. The Natwest Market case in February 1997 suffered a loss of GBP 90.5 Million as a result of interest rate options and swaption trading. The problem occurs systemic mispricing of various options and swaption instruments by traders in the rate risk management group.

That is why risk measurement and risk management are so important. In 2004 Bank Indonesia (BI) required all commercial banks to implement risk management. However, risk management is meaningless for banks if it is not accompanied by the ability to measure the magnitude of the risk itself.

\section{Concept Value at Risk (VaR)}

One technique for measuring risk is Value at Risk (VaR). VaR can be defined (Ghozali, 2007): "VaR measures the worst expected loss over a given horizon under normal market conditions at a given confidence level. So VaR can be interpreted as the size of the worst losses that are expected to occur at a certain time horizon under normal market conditions with a certain level of confidence. According to Jorion (2001) in Abad et al., (2014) VaR measures are defined as the worst losses expected during certain horizons under normal market conditions at a certain level of trust. Many financial institutions and regulators look at the VaR method as an easy tool for understanding and measuring market risk.

$\mathrm{VaR}$ is a concept that is often used in risk measurement and risk management. VaR is defined as the estimated value of the maximum loss that may occur in a certain period with a certain level of confidence and normal market conditions. From this definition, VaR statistics have three components namely: time period, confidence level, and total loss (or percentage loss). The following table is the level of confidence (confidence level) for VaR

Table 1. Confidence Level

\begin{tabular}{|c|c|}
\hline Confidence Level & Standard Deviation \\
\hline 95\% (high) & 1,65 \\
\hline $99 \%$ (really high) & 2,33 \\
\hline
\end{tabular}

Source: D. Harper, 2004 quoted by Prabowo, (2009) 
The $95 \%$ confidence value gives a 1.65 confidence factor assuming a normal distribution, so the $99 \%$ confidence level gives a factor value of 2.33 .

There are three VaR measurement methods, namely parametric (without data), nonparametric (based on historical data) and Monte Carlo simulations (based on future data) (Adrianto et al., 2017):

a. Parametric method (without data) or covariance variance method This method assumes the return of risk is normally distributed, the correlation between risk factors (sensitivity or price to changes in risk factors) is constant and the delta of each constituent's portfolio is constant. Using the correlation method, the volatility of each risk factor is extracted from the history of the observation period. The formula for this method is:

Description:

$$
\mathrm{VaR}=\mathrm{PZ}_{0,95} \sigma \sqrt{\mathrm{t}}
$$

$\mathrm{PZ}_{0,95} \quad$ : confidence level $95 \%$

$\sigma$ : single asset return volatility

$\sqrt{\mathrm{t}}$ : the period

b. Monte Carlo Simulation Method. This method is non-parametric because it does not use the assumption of a normal distribution. The difference with historical simulation lies in the ability of this method to produce thousands of simulation pathways to produce an almost accurate distribution of the distribution of risk factors in the future. The formula for this method is:

Description :

$$
\mathrm{VaR}=\mu-(\mathrm{Z} \times \sigma)
$$

VaR: Maximum potential loss

$\mu$ : The value of the average return

Z: Confidence level

$\sigma:$ Standard deviation

c. Historical Simulation Method. This method is also non-parametric. This method is the easiest way to estimate Value At Risk for many portfolios. In this method, the VaR for a portfolio is estimated by creating a hypothetical time series of returns obtained by running a portfolio through actual historical data and changes that have occurred in each period of a portfolio. In this method, VaR is determined by actual price movements. The formula for this method is:

Description:

$$
\operatorname{VaR}_{(1-\alpha)}=\mu(\mathrm{R})-\mathrm{R} \alpha
$$

$\mathrm{VaR}_{(1-\alpha)}$ : Maximum potential loss

$\mu(\mathrm{R})$ : Average value of the return

$\mathrm{R} \alpha$ : The maximum loss of certain $\alpha$

\section{Framework}

Based on this theory, it can be used as a basis for formulating problems in the form of a framework of thought as follows: 


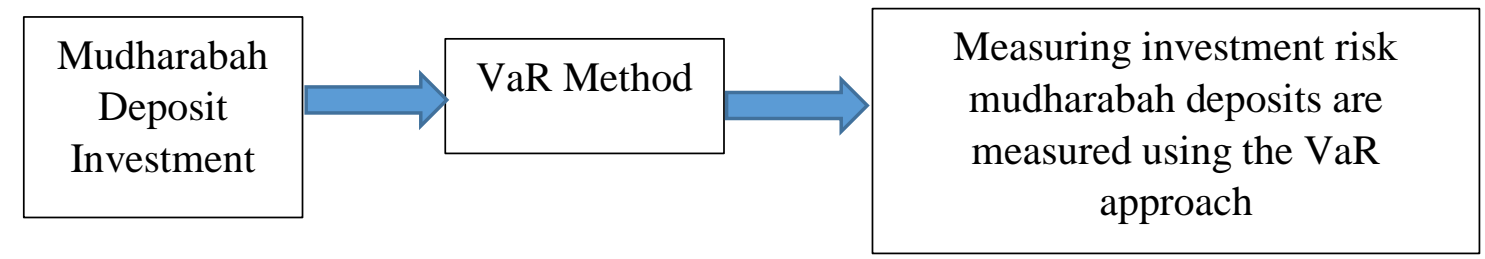

Figure 1

Framework of thinking

Deposit investment is a form of investment that is quite attractive. This study analyzes the risks in mudharabah time deposit investments with the Value at Risk (VaR) approach, namely how much is the maximum potential loss of investors (depositors) in mudharabah time deposit investments during the time horizon $\mathrm{t}$ (a year) with a certain level of confidence (confidence level). Also, Value at Risk (VaR) measures the net return offered by Mandiri Syariah Banks, BRI Syariah Banks, and Muamalat Banks.

\section{Research Methods}

This research method illustrates a statistical analysis in which to find out the risk weight and net return of mudharabah deposit investments in Islamic commercial banks using the Value at Risk (VaR) approach.

This study takes the population at a Sharia Commercial Bank in Indonesia. The sampling method was purposive sampling with criteria:

a. Sharia Commercial Bank in Indonesia

b. Sharia Commercial Bank which publishes complete quarterly financial reports from 2015-2017.

Based on these criteria, the object of this study is 3 Sharia Commercial Banks, namely Syariah Mandiri Bank, BRI Syariah Bank, and Muamalat Bank. The quantitative data in this study consisted of each quarterly Financial Report Publication for the 2015-2017 period. Data includes the amount of mudharabah deposit investment and the distribution of revenue sharing from mudharabah deposits. Data obtained for risk analysis and mudharabah net return using the VaR method.

\section{Analysis Instruments}

The analytical tool in this study uses the Value at Risk (VaR) approach. The Value at Risk (VaR) approach can be explained as follows:

a. The risk measurement method is calculated by estimating the percentage of potential losses through VaR absolute values and relative values. Absolute VaR is a loss to zero and relative $\mathrm{VaR}$ is a loss compared to the average expected return. Estimation of the VaR approach can be seen with the following formulation:

\begin{tabular}{|ll|}
\hline $\operatorname{VaR}($ mean $)$ & $=\mathrm{A} 0 \alpha \sigma \sqrt{\mathrm{T}}$ \\
\hline $\operatorname{VaR}($ zero $)$ & $=\mathrm{A} 0(\alpha \sigma \sqrt{\mathrm{T}}-\mu \mathrm{T})$ \\
\hline
\end{tabular}


Description:

A0: Shows the amount of value invested at the rate of return of mudharabah deposits

$\alpha \quad$ : Shows the normal standard distribution

$\sigma \quad$ : Shows the standard deviation

$\mathrm{T}$ : Shows the time interval which is determined in years (3 months means $3 / 12)$ and $\mu$ : Indicates the expected return rate.

b. Absolute $\mathrm{VaR}$ and relative $\mathrm{VaR}$ use the parametric method multiplied by two quantitative parameters, namely the confidence level and the time horizon due to the nature of the measurement is the estimation. The level of confidence is based on a normal standard distribution value () which can be found from the normal curve table of 1.65 for the confidence level (95\% and 2.33 for the $99 \%$ confidence level. Measuring VaR is better using a higher level of confidence. confidence levels provide useful information about the distribution of returns and potential extreme losses.

c. The expected rate of return is used to measure the average estimate or estimate of the probability distribution obtained from the revenue sharing on mudharabah deposits. The standard deviation shows that if the greater the standard deviation of returns, the greater the variable of return and the higher the risk of the investment. In the application of this study, the investment risk of mudharabah deposits can be seen in total (total risk) through the standard deviation. Where the standard deviation measures the percentage measure of distance or fluctuation of the average variable return value of the expected results. In its application, the standard deviation is the sum of the squares of the equivalent rate value (distribution of revenue sharing for mudharabah deposits) (Xi) minus the variable mean value (mean) equivalent rate for the results of mudharabah deposits (Xi) divided by the number of time periods (N) quarterly in a year, namely 2015-2017 (Prabowo, 2009).

\section{Results and Discussion}

This research will analyze the investment risk of mudharabah deposits using the VaR analysis approach. The relationship between Gross Expected Return and VaR (mean) and VaR (zero) is as follows (Ghozali, 2007):

a. Prospective value, if there is a large return with a small risk (low-risk high return)

b. Fair value, if there is a large return with a large risk (high-risk high return) or there is a small return with a small risk (low-risk low return).

c. The value of potential losses, if there is a small return with a large risk (high-risk low return).

Based on the explanation above, it can be described the results of the investment risk analysis of mudharabah time deposits (1,3,6 and 12 months) at Bank Syariah Mandiri in 20152017 using the VaR analysis approach as follows: 


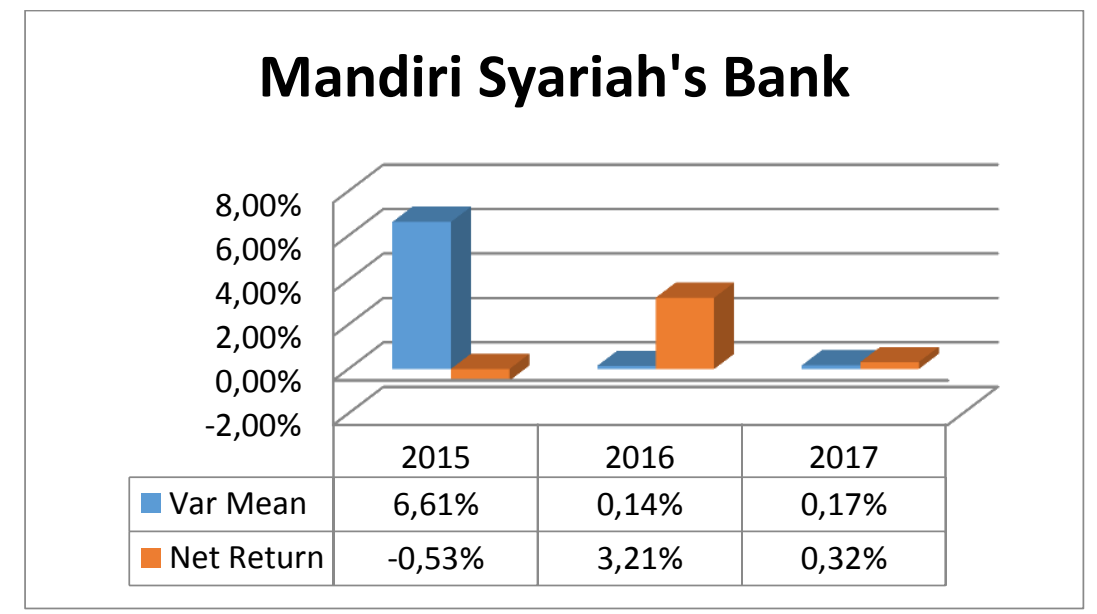

Source: Data processed, 2019

Figure 1. Risk Level (VaR Mean) and Expected Return on Bank Syariah Mandiri in 2015-2017

Based on the picture above, the Syariah Mandiri banks in 2015 had the highest risk level of $6.61 \%$ with the lowest return of $-0.53 \%$. This is according to the quarterly report of Syariah Mandiri banks in 2015 having 7,229 Trillion. Whereas in June until December, it averaged 30 trillion. This means that during 2015, Syariah Mandiri banks had high volatility, resulting in high standard deviations so that the level of risk was also high. In 2016, the independent Syariah Bank had a risk level of $0.14 \%$ and a return of $3.21 \%$. This can be explained by the independent Islamic banks in 2016 starting to be more stable in providing revenue sharing mudharabah deposits. In 2017 the independent Islamic bank experienced a decline compared to 2016. In 2017 the risk level rose to $0.17 \%$ and the return dropped to $0.32 \%$.

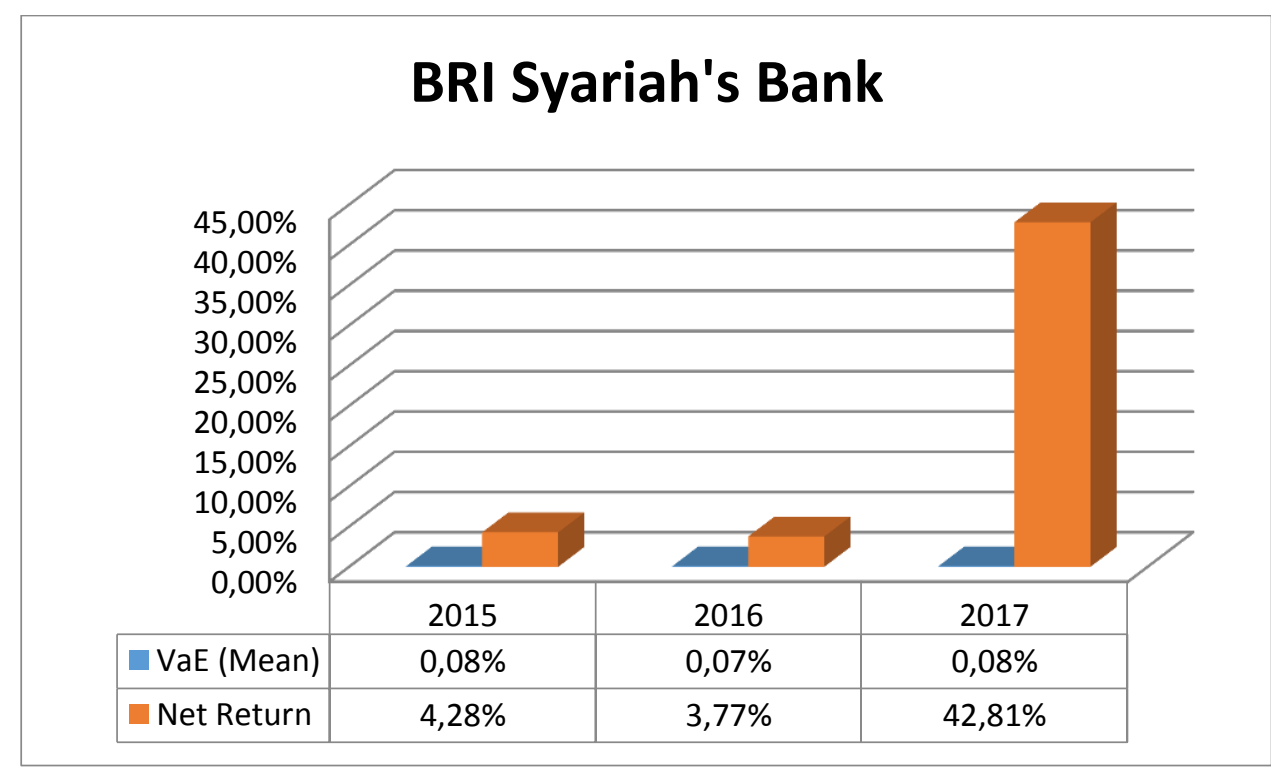

Source: Data processed by VaR, 2019

Figure 2. Risk Level (VaR Mean) and Expected Return on

Bank Syariah Syariah in 2015-2017 
Based on the picture above, Bank BRI Syariah in 2015 has a risk level of $0.08 \%$ with a Net Return of 4.28\%. In 2016, Bank BRI Syariah had the lowest risk level of $0.07 \%$ and a rate of return of 3.77\%. In 2017 Bank BRI Syariah experienced an increase in the risk level of $0.08 \%$ with Net Return increasing by $4.28 \%$ as in 2015. The low level of risk at Bank BRI Syariah in 2015-2017, meant Bank BRI Syariah on the average stable in providing returns to mudharabah deposit investors.

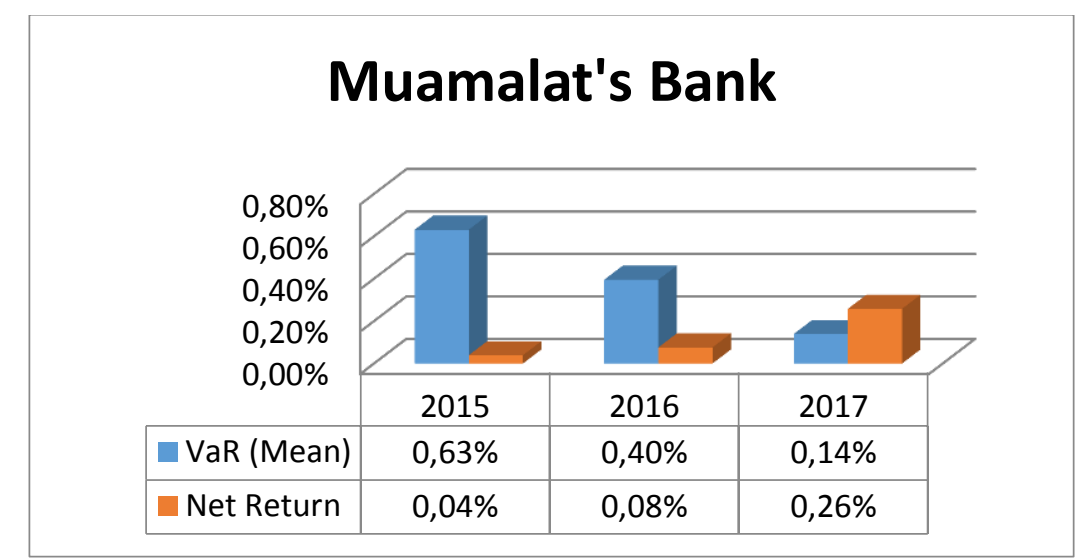

Source: Data processed 2019

Figure 3. Risk Level (VaR Mean) and Expected Return on

Bank Muamalat in 2015-2017

Based on the picture above, Bank Muamalat in 2015 and 2016 experienced the highest risk compared to 2017 and in 2015-2016 with a low return, this condition was caused by Bank Muamalat in a declining financial condition in the last few years. In 2017 Muamalat banks began to stabilize with risks dropping drastically from risks in 2016 from the risk of $0.40 \%$ to 2017 of $0.14 \%$ with the highest return of $0.26 \%$.

Table 2. Investment Risk Mudharabah Deposit Bank Mandiri Syariah, BRI Syariah Bank and Muamalah Bank 2015-2017

\begin{tabular}{|l|c|c|c|}
\hline \multicolumn{1}{|c|}{$\begin{array}{c}\text { Sharia Commercial } \\
\text { Bank }\end{array}$} & 2015 & 2016 & 2017 \\
\hline Syariah Mandiri's Bank & $6,61 \%$ & $0,14 \%$ & $0,17 \%$ \\
\hline BRI Syariah's Bank & $0,08 \%$ & $0,07 \%$ & $0,08 \%$ \\
\hline Muamalat' Bank & $0,63 \%$ & $0,40 \%$ & $0,14 \%$ \\
\hline
\end{tabular}

Source: Data Processed, 2019

Based on the above table, the movement of the risk level of mudharabah investment deposits at Bank Syariah Mandiri was very high in 2015 and experienced a sharp decline in 2016 and 2017. This is because based on the number of deposit returns in the first quarter of 2015 Bank Syariah Mandiri, was very high, and decreased sharply in the second quarter of 2015. This sharp fluctuation caused Bank Syariah Mandiri to have very high volatility in 2015. This also 
meant having a high risk during 2015. While BRI sharia banks had the lowest and most stable risk levels. from Bank Syariah Mandiri and Bank Muamalat. This is because volatility in Islamic banks tends to be stable so that the standard deviation is low. At Muamalat Bank has high risk in 2015 and 2016. In 2015 and 2016 Bank Muamalat provided mudharabah deposit returns which were quite volatile so that the risk was high. But in 2017 returns tend to be stable so the risk is low at $0.14 \%$.

The table above only shows the percentage of risk of the three Islamic banks. As an investor, of course, they have their own choices in determining which Islamic bank to invest in. As an investor other than risk, a given return is also important to be considered in mudharabah deposit investments.

Table 3. Expected Return Returns on mudharabah deposits of Syariah Mandiri's Bank, BRI Syariah's Bank and Muamalat's Bank in 2015-2017

\begin{tabular}{|l|c|c|c|}
\hline Sharia Commercial Bank & 2015 & 2016 & 2017 \\
\hline Syariah Mandiri's Bank & $-0,53 \%$ & $3,21 \%$ & $0,32 \%$ \\
\hline BRI Syariah's Bank & $4,28 \%$ & $3,77 \%$ & $42,81 \%$ \\
\hline Muamalat's Bank & $0,04 \%$ & $0,08 \%$ & $0,26 \%$ \\
\hline
\end{tabular}

Source: Data Processed 2019

Based on the above table, the movement of expected return on investment returns from mudharabah deposits at Bank Syariah Mandiri is quite high in 2016 and 2017. But it has experienced a minus in 2015. Minus here does not mean loss, but it means the risk is far greater than expected return in 2015. Bank BRI Syariah in terms of expected return shows results that rose significantly in 2017 , amounting to $42.81 \%$. BRI Syariah is still superior in terms of return given the highest percentage compared to Bank Syariah Mandiri and Bank Muamalat. Whereas Muamalat Bank has the lowest return.

As an investor, high risk is not something to be avoided. As long as high risk is followed by high returns, this will be an interesting challenge. Based on the analysis of the three Sharia Commercial Banks above, BRI Syariah Syariah was the best, which during 2015-2017 had the lowest risk level, the most stable and the highest return.

\section{Conclusion}

Based on the results of research and discussion on investment risk analysis of mudharabah deposits and returns, it can be concluded that BRI Syariah banks are the most superior in becoming the choice in investing mudharabah deposits. BRI Syariah Bank after measured by Value at Risk has the lowest and most stable risk (VaR Mean), $0.08 \%$ in 2015, $0.07 \%$ in 2016, and $0.08 \%$ in 2017. In addition to the low-risk level, BRI Syariah banks had the highest expected rate of return for three years of observation, namely $4.28 \%$ in $2015,3.77 \%$ in 2016, even in 2017 the expected return was $42.81 \%$. This study has several limitations that can affect research results. These limitations include: first, this research was only conducted on 3 Islamic banks, namely Syariah Bank Mandiri, BRI Syariah Bank, and Muamalat Bank alone during the 2015-2017 period. Second, the latest data used is secondary data in 2017 taken from the publication of the financial statements of each bank studied about determining the level of profit and risk on Mudharabah Deposit investments. Based on the results of the conclusions and limitations above the authors provide suggestions: first, efforts to overcome the risk of 
mudharabah deposit investment can be taken by bank management, namely banks must have a good administration system in the bank's daily budget system, both from internal and external sources of the bank. Second, for investors and Islamic banking, they are better able to manage risk and try to apply the Value at Risk (VaR) risk analysis method as a risk measurement tool, so they can make more informed decisions, and the last hope this research can be a reference for future research, so that better and more useful results can be obtained.

\section{References}

Abad, P., Benito, S., \& López, C. (2014). A comprehensive review of Value at Risk methodologies. The Spanish Review of Financial Economics, 12, 15-32. https://doi.org/http://dx.doi.org/10.1016/j.srfe.2013.06.001

Adrianto, A. D., Azhari, M., Khairunnisa, S. E., \& Carlo, M. (2017). Analisis Value At Risk Dengan Metode Historis , Dan Monte Carlo Dalam Saham Sub Sektor Rokok ( Studi Kasus Pada Saham Gudang Garam Dan Hm Sampoerna ). Analysis Of Value At Risk With Historical Methods, And Monte Carlo In The Stock Sub Sectors Of Cigarett. E-Proceeding of Management, 4(2), 1437-1444. https://libraryeproceeding.telkomuniversity.ac.id/index.php/management/article/view/766

Al Anshori, A. G. (2009). Trend Pembentukan Bank Umum Syari'ah Pasca Undang-Undang Nomor 21 Tahun 2008 :Konsep, Regulasi, dan Implementasi. BPFE-YOGYAKARTA.

Dewan Komisioner Otoritas Jasa Keuangan. (2016). Peraturan Otoritas Jasa Keuangan Nomor 18 /POJK.03/2016 Tentang Penerapan Manajemen Risiko Bagi Bank Umum. https://www.ojk.go.id/id/kanal/perbankan/regulasi/peraturan-ojk/Pages/POJK-Nomor18.POJK.03.2016.aspx

Dewan Syariah Nasional. (n.d.). Fatwa DSN No. 03/DSN-MUI/IV/2000 Tentang Deposito. http://hukum.unsrat.ac.id/inst/deposito.pdf

Fahmi, I. (2011). Analisis Laporan Keuangan. Alfabeta.

Ghozali, I. (2007). Manajemen Risiko Perbankan: Pendekatan Kuantitatif Value at Risk (VaR). Badan Penerbit Universitas Diponegoro.

Hermansyah. (2017). Estimasi Value At Risk Dengan Distribusi Normal Untuk Memprediksi Return Investasi. Mercumatika, Jurnal Penelitian Matematika Dan Pendidikan Matematika, 1(2), 92-96. https://doi.org/10.26486/mercumatika.v1i2.250

Hidayati, L. N. (n.d.). Mengukur Risiko Perbankan Dengan VaR (Value at Risk). https://adoc.tips/queue/mengukur-risiko-perbankan-dengan-var-value-at-risk-oleh-lina.html

Ismail. (2014). Perbankan Syariah. (1st ed.). Kencana Prenadamedia Grup.

Ismanto, H. (2016). Analisis Value At Risk Dalam Pembentukan Portofolio Optimal (Studi Empiris Pada Saham-Saham Yang Tergabung Dalam LQ45). The 3 Rd University Research Colloquium, 243-255. https://publikasiilmiah.ums.ac.id/bitstream/handle/11617/6737/23. Hadi Ismanto.pdf?sequence $=1 \&$ is Allowed $=y$

Jogiyanto. (n.d.). Partial Least Square (PLS) Alternatif Structural Equation Modeling (SEM) 
dalam Penelitian Bisnis (1st ed.). ANDI.

Musthofa, U. A., \& Prastiwi, I. E. (2016). Analisis Risiko Investasi Deposito Mudharabah. Jurnal Ilmiah Ekonomi Islam, 02(02), 73-84.

Prabowo, Y. (2009). Analisis Resiko dan Pengembalian Hasil pada Perbankan Syariah : Aplikasi Metode VaR dan RAROC pada Bank Syariah Mandiri. La Riba: Jurnal Ekonomi Isam, III(1), 90-105. https://docplayer.info/40842062-Analisis-resiko-dan-pengembalian-hasilpada-perbankan-syariah-aplikasi-metode-var-dan-raroc-pada-bank-syariah-mandiri.html

Saddique, A. A., \& Khan, N. U. (2016). Value at Risk in Banking Sector of Pakistan. PUTAJHumanities and Social Sciences, 22(2), 143-151.

https://www.researchgate.net/publication/311824189

Zuhara, U., Akbar, M. S., \& Return, A. P. (2012). Penggunaan Metode VaR ( Value at Risk ) dalam Analisis Risiko Investasi Saham dengan Pendekatan Generalized Pareto Distribution ( GPD ). JURNAL SAINS DAN SENI ITS, 1(1), 56-61.

https://doi.org/10.12962/j23373520.v1i1.959 